\title{
On the taxonomic placement of the genus Sinnamarynus (Hemiptera: Heteroptera: Reduviidae), and a new record of $S$. rasahusoides from Peru
}

\author{
María Cecilia Melo \\ Instituto de Limnología “Dr. R.A. Ringuelet” (ILPLA, CCT- La Plata, CONICET- UNLP), Departamento Sistemática, CC 712 (1900) La Plata, Argentina. \\ E-mail: cecimelo@ilpla.edu.ar
}

\begin{abstract}
The genus Sinnamarynus Maldonado Capriles and Bérenger, 1996 (Hemiptera: Heteroptera: Reduviidae), originally placed into the subfamily Reduviinae, is transferred to the subfamily Peiratinae. Dorsal habitus and the male genitalia of the type species, S. rasahusoides Maldonado Capriles and Bérenger, 1996 are illustrated. The genus and species are recorded for the first time from Peru.
\end{abstract}

The genus Sinnamarynus was established by Maldonado Capriles and Bérenger (Bérenger et al. 1996) to include the newly described species $S$. rasahusoides. The authors placed the genus into the subfamily Reduviinae with no arguments. They mentioned the remarkable similarity of $S$. rasahusoides with the sympatric peiratine species Rasahus sulcicollis (Serville, 1831), and referred to other cases of sympatric species of similar appearance, but did not discuss the characters that make the similarity so remarkable.

Reduviinae contains approximately 140 genera and about 980 species and shows a worldwide distribution (Maldonado Capriles 1990; Ishikawa et al. 2005). The subfamily cannot be characterized by synapomorphies, but it is defined mainly by the absence of apomorphies occurring in other reduviid subgroups (Schuh and Slater 1995). A recent phylogenetic analysis presented by Weirauch (2008) demonstrated its polyphyletic nature; in contrast, the monophyly of subfamily Peiratinae is well supported by the following characters: presence of a row of sensillar pits on maxillary apex; presence of lobe-like processes on ventral gap of left maxillary stylet; enlarged protibial fossula spongiosa; asymmetric male genitalia; presence of a median guiding structure on valvifer 1 and valvula 1; and presence of a bulbous structure on valvula 2 .

Aside from the material mentioned in the description of S. rasahusoides, deposited at Muséum National d'Histoire Naturelle, Paris, France (MNHN), no other specimens have been found so far. The genus with its single included species has only been known from French Guiana. Studying the entomological collection of the Museo de Ciencias Naturales de La Plata, Buenos Aires, Argentina (MLP), a new male was found from Peru. After studying the holotype and the Peruvian specimen it was concluded that the genus should be placed into the subfamily Peiratinae. The characters supporting this decision are described and illustrated in the present paper.

\section{Sinnamarynus Maldonado Capriles and Bérenger, 1996}

Sinnamarynus Maldonado Capriles and Bérenger, 1996: 251, 255. Type species by original designation: S. rasahusoides Maldonado Capriles and Bérenger, 1996: 252.

Sinnamarynus: Forero, 2004: 161 (diagnosis, distribution), 188 (in key).

Sinnamarynus: Gil Santana and Coletto Silva, 2005: 297-298 (in key).

Diagnosis: Small size, and robust. Head short, anteocular region short; preocellar transverse groove deeply impressed; antenna thick, scapus curved, relative antennal segment length II $>$ III=IV $>$ I; eyes globose and protruding; rostrum robust, second segment the longest; anterior lobe of pronotum quadrangular, longer than posterior lobe, humeral angles rounded; metapleural suture straight; femora incrassate, ventral surface with strong protuberances bearing a stiff setae at apex; fossulae spongiosa present on anterior and middle tibiae; corium elongate, covering $3 / 4$ of abdomen; abdominal venter flattened; male genitalia asymmetrical (figs. 2-8): posterior process of pygophore bent laterally to the right (figs. 3-4), left paramere enlarged (figs. 5-6)

Discussion: The examination of the material and the photographs of the male holotype, confirm that this species should be included in the subfamily Peiratinae and not within Reduviinae. Following the phylogenetic analysis of Weirauch (2008), the characters found in Sinnamarynus rasahusoides that support this placement are: the elongate anterior lobe of foretibial fossula spongiosa, and the asymmetry of the male genitalia (figs. 2-8); other characters, such as those related to the mouthparts and to the female genitalia were not examined owing to the scarcity of material and the destructiveness of the approach. The female of this species remains unknown.

The subfamily Peiratinae is represented in the Western 


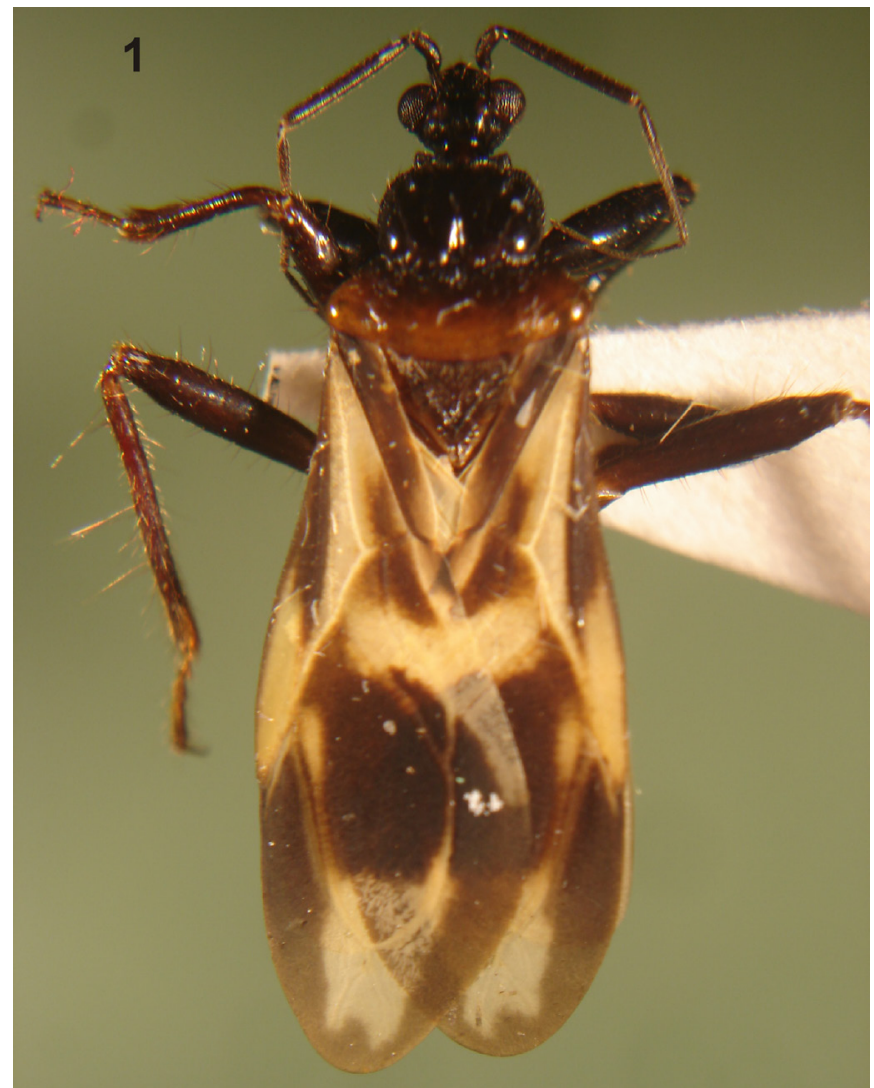

FIGURE 1. Sinnamarynus rasahusoides Maldonado Capriles and Bérenger, dorsal habitus.

2

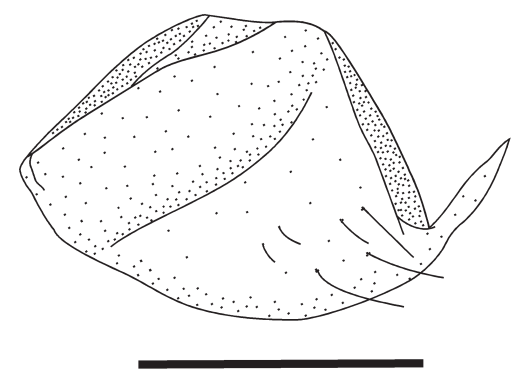

3

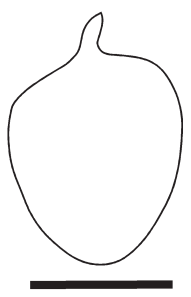

5

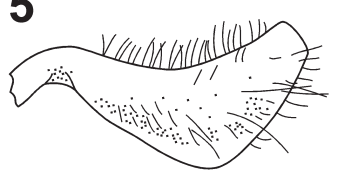

6

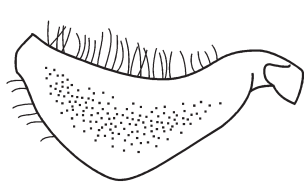

7
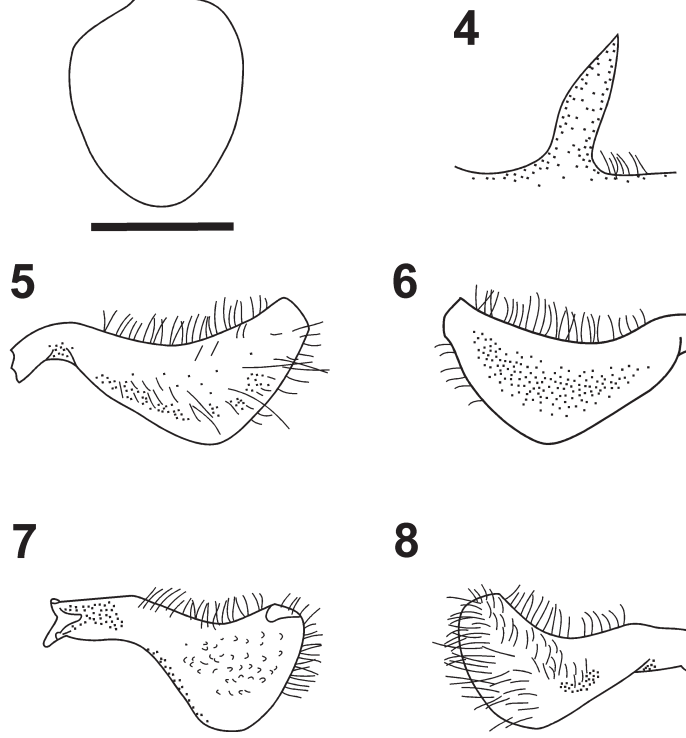

8

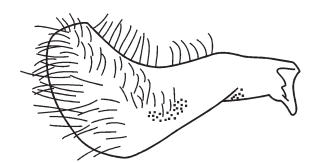

Hemisphere by 10 genera and 70 species. Sinnamarynus keys to couplet 3 in Cai and Taylor's (2006) key to the New World genera, together with Tydides Stål from which can be distinguished by the relatively shorter anterior region of head, the less elongate procoxae, the bicolored connexiva, and the shape of parameres.

\section{Sinnamarynus rasahusoides Maldonado Capriles and Bérenger, 1996 (Figures 1-8)}

Sinnamarynus rasahusoides Maldonado Capriles and Bérenger, 1996: 252.

Type material examined: (from dorsal and lateral view photographs) HOLOTYPE (male), Guyane, Cirad, Paracou Sinnamary, 10-IX-1993, at light, leg. Bérenger J.M. (MNHN).

Additional material examined: Peru: 1 male, Cuzco, Pagoreni, 1142'22" S 7254'07" W, VI-2004, Williams col. (MLP).

Distribution: French Guiana, Peru (FIRST COUNTRY RECORD).

ACKNOWLEDGMENTS: I am grateful to Sara I. Montemayor (División Entomología, Museo de La Plata, Argentina) for the photographs of the type specimen at the MNHN, and comments on the manuscript. This work was funded by the Consejo Nacional de Investigaciones Científicas y Técnicas (CONICET), Argentina.

\section{Literature Cited}

Bérenger, J.M., J. Maldonado Capriles, and D. Pluot-Sigwalt. 1996. Un nouveau genre de Reduviinae de Guyane et notes sur la sous-famille (Heteroptera, Reduviidae). Bulletin de la Société entomologique de France 101: 251-256.

Cai, W. and S.J. Taylor. 2006. Lentireduvius, a new genus of Peiratinae from Brazil, with a key to the New World genera (Hemiptera: Reduviidae). Zootaxa 1360: 51-60.

Forero, D. 2004. Diagnosis de los géneros Neotropicales de la familia Reduviidae (Hemiptera: Heteroptera) y su distribución en Colombia (excepto Harpactorinae); pp. 129-275 In F. Fernández, G. Andrade and G. Amat (ed.) Insectos de Colombia, vol. 3. Bogotá: Universidad Nacional de Colombia.

Gil Santana, H.R. and A. Coletto Silva. 2005. Berengeria rafaeli, gen. nov., so. nov. de Reduviinae da reserva Ducke, Estado do Amazonas, Brasil (pemiptera- Heteroptera, Reduviidae). Acta Amazonica 35(2): 397300.

Ishikawa, T., W. Cai and M. Tomokuni. 2005. A revision of the Japanese species of the subfamily Reduviinae (Insecta: Heteroptera: Reduviidae). Species Diversity 10: 269-288.

Maldonado Capriles, J. 1990. Systematic Catalog of the Reduviidae of the World (Insecta: Heteroptera). Caribbean Journal of Science Special Edition: 1-694.

Schuh, R.T. and J.A. Slater. 1995. True bugs of the World (Hemiptera: Heteroptera). Classification and natural history. Ithaca and London: Cornell University Press. 336 p.

Weirauch, C. 2008. Cladistic analysis of Reduviidae (Heteroptera: Cimicomorpha) based on morphological characters. Systematic Entomology 33: 229-274.

RECEIVED: February 2012

ACCEPTED: April 2012

Published ONLINE: June 2012

EDITORIAL RESPONSIBILITY: Ricardo Ribeiro de Castro Solar outer view; (6) left paramere, inner view; (7) right paramere, outer view; (8) right paramere, inner view. Scale line $1 \mathrm{~mm}$. 